\title{
BENEFICIAL EFFECTS OF MARINE ALGAE IN SKIN MOISTURIZATION AND PHOTOPROTECTION
}

\author{
Haresh S. Kalasariya ${ }^{1}$, Dr. Mehul P. Dave ${ }^{2}$,Dr. Virendra Kumar Yadav ${ }^{3}$ Dr. Nikunj B.
Patel $^{*}$.
${ }^{*}$ Department of Microbiology \\ Smt. S. S. Patel Nootan Science \& Commerce College, \\ Sankalchand Patel University, Visnagar-384 315 \\ ${ }^{2}$ Life Science Department, Indian Institute of Teacher Education, Gandhinagar \\ ${ }^{3}$ School of Life Sciences, Jaipur National University, Jaipur, Rajasthan \\ ${ }^{1}$ hareshahir22@gmail.com, \\ 201rmehulpdave@gmail.com, ${ }^{3}$ yadava94@gmail.com, ${ }^{*}$ niks17micro@gmail.com
}

\section{ABSTRACT}

Among marine organisms, marine algae are rich sources of diversified bioactive constituents with various potential biological activities. It contains many natural phycocompounds such as polysaccharides, fatty acids, amino acids, vitamins, minerals, phenolic compounds, etc. that are utilized for various industrial applications. Nowadays, seaweed received great attention in cosmeceutical applications for skin health benefits. It exhibits a wide range of biological activities in cosmetics such as skin whitening, moisturizer, photoprotection, antiwrinkle, antiaging, antimicrobial activities, etc. The present review study aims to check the applicability of marine macroalgae in moisturizing the skin and protection of the skin against UV damaging effects. This overview further helpful in the evaluation and development of marine algae in cosmeceuticals applications.

Keywords: Cosmetics, Marine macroalgae, Photoprotection, Phytocompounds, Skin moisturizer

\section{Corresponding Author:Dr. Nikunj B. Patel}

\section{INTRODUCTION}

Algae are a class of photosynthetic organisms found in marine as well as freshwater habitat. ${ }^{1}$ It contains diversified photosynthetic pigments that are helpful to prepare food for themselves. ${ }^{2}$ Mainly algae are of two types: Macroalgae and Microalgae. The former one is similarly known as seaweed, multicellular eukaryotic photosynthetic organisms belong to Plantae kingdom. ${ }^{3,5}$ It is macroscopic, benthic, and up to 50 meters in length. Normally, it can be divided mainly into three types: red algae (Rhodophyta), green algae (Chlorophyta), and brown algae (Phaeophyta). ${ }^{2}$ Algae are found in shallow water, in the tidal, subtidal or intertidal zone. It is found anchoring with rocks, corals, shells, pebbles, sand, plants, or in floating form. ${ }^{6}$

Marine algae possess a huge pigment diversity such as red algae contain chlorophyll a, chlorophyll b, phycobilins, r-phycocyanin, r-phycoerythrin, carotenoids, lutein, B-carotene, etc. Along with brown algae possess chlorophyll a, chlorophyll c, carotenoids, fucoxanthin whereas green algae contain green pigment such as chlorophyll a and b, carotenoids, etc. ${ }^{7}$ 
Marine macroalgae are widely distributed along the coast of India as well as Gujarat coastal line. The Indian coastline is about $7500 \mathrm{~km}$ long and many different sites such as Mandapam, Vishakhapattanm, Kerala, Thiruvananthapuram, Ramnathpuram are a rich source of seaweed diversity. ${ }^{8,9}$ The coast of Gujarat comprises two gulfs namely the Gulf of Kachchh and the Gulf of Khambhat. Both the Gulf showed huge varieties of different marine algal species in various regions such as Okha, Veraval, Beyt Dwarka, Mandavi, Bhavnagar(Ghogha, Gopnath, Bhavani), etc. ${ }^{10,11,12}$ Marine macroalgae rich in nutritional components such as primary and secondary metabolites. It is rich in carbohydrates, proteins, lipids, amino acids, mycosporin amino acids(MAAs), fatty acids, phenolic compounds, sterols, pigments, minerals, and vitamins. ${ }^{13}$ Due to the rich diversity of such novel constituents, it is a widely underexplored resource of the designing and production of novel products. With over increasing life expectancies among people around the world. the physical appearance of skin concern is increasingly becoming a common cosmeceutical approach. ${ }^{14}$ Cosmetics are the preparation of some ingredients to enhance, to improve, or alter the function and appearance of the skin. ${ }^{15}$ Nowadays, Peoples are more attentive to the formulation of anti-aging, skin whitening, photoprotection, moisturization, etc. ${ }^{16}$

Instead the huge demands of cosmetic products by people encouraging the future of the cosmetic industry. To satisfy the customer's requirements, industries are trying to develop many cosmetic products with some synthetic ingredients. Many synthetic chemicals have been used in formulations such as PHA, PHB, Oxybenzone, BHA, BHT, DEA, MEA, etc. ${ }^{16}$ These types of chemical constituents accumulate in the skin layers and cause some damaging effects such as dermatitis, Dryness, skin blotches, white patches, cancer, wrinkle formation, etc. ${ }^{17,18,19}$ The overexploitation market for skin products and continual search for innovative ingredients have led to the development of natural products. ${ }^{20}$ To overcome these harmful effects as well as in search of an alternative, Marine algae is widely used as a natural source of bioactive compounds for functional cosmetic applications. ${ }^{21}$ Seaweed phycocomponents such as carbohydrates, sulfated polysaccharides, fucoidan, carrageenan, oligosaccharides, terpenoids, carotenoids, tocopherol, phenolic compounds, phlorotannins, carrageenan oligosaccharides, crude polysaccharides needful for imparting many biological activities such as antioxidant, anti-inflammatory, anti-tumor, anti-allergic, antimelanogenesis, anti-skinaging, anti-atopic dermatitis, anti-skin cancer, anti-oxidative photoprotection, etc. $^{22,23,24,25,26,27,28,29,30,31}$

Skin is the main sensory organ of the human body and its properties get damaged by overexposing of Ultraviolet (UV). UV radiation is harmful to skin as well as forms ROS(Reactive oxygen species). It also proved to be mutagenic, carcinogenic and dehydrates the skin. These problems required a lot of attention to natural alternatives. ${ }^{32}$ There are many marine algae-derived bioactive compounds such as squalene, polysaccharide, proteins, phenolic compound helpful in skin curation, and revealed treating effects against skin inflammation, dehydration, skin-soothing, photo damaging activity, etc. ${ }^{33,34,35,36,37,38,39}$

Water is essential for skin characteristics such as flexibility, normal functioning such as maturation and desquamation of the skin. ${ }^{40}$ Flynn et al. (2001) suggested Stratum Corneum(SC) can hold water(20-35\%) and acts as a barrier to prevent loss of water. ${ }^{41}$ According to them, less than $10 \%$ of water content create roughness and dryness of the skin. This problem creates attention towards maintaining water holding capacity will improve flexibility and normal functions of the skin. ${ }^{42}$ Some synthetic humectants increase trans epidermal water loss or create toxicity. Another alternative such as natural humectants contains MAAs, polysaccharides, lipids, proteins, etc. helpful in such activities. ${ }^{43,44,45}$ Due to the harmful effect of UV radiation on the skin, leading to dryness or dehydration and reduce the elasticity of the skin. ${ }^{46}$ Due to the negative consequences of using chemical ingredients, 
there are many species of marine algae showed the presence of potential metabolites that responsible for moisturizing the skin or act as a UV filter. ${ }^{47}$

\section{REVIEW ON MOISTURIZING ACTIVITY}

Varsha Vaibhav and Sangeeta Sahasrabuddhe, (2018) suggested various beneficial applications of macroalgae including cosmetics such as in the treatment of skin aging, tanning, prevention of roughness, skin wrinkles, whitening, and antibrowning reaction. ${ }^{48}$ Valentina Jesamani et al. (2019) reviewed on potential uses of seaweed bioactive compounds in skincare such as hyperpigmentation, premature skin aging, acne, photoprotection, etc. ${ }^{15}$ Carbohydrates for skin health-beneficial to the skin such as antioxidant, anti-melanogenic, skin antiaging, etc. ${ }^{43}$ Bioactive compounds of marine algae play their role in skin hydration and protection. ${ }^{49,14}$ Marine algae as a natural source(safer and equally effective) to enhance skin appearance by moisturizing and protecting against damaging UV rays. ${ }^{50,51}$ Extract of seaweed Laminaria japonica extracts on skin moisturization checked in vivo by Surbhi Joshi et al. (2018). It possesses a promising ingredient which can be useful for this activity. ${ }^{52}$ SnezanaAgatonovic-kastrin and David W Morton, (2013) reported the presence of bioactive compounds (such as terpenoids, polysaccharides-fucoidan, carrageenan, alginates, etc.) and its activity in skin moisturization. ${ }^{53}$ Different marine algae are used for studying its application in skin moisturization by various researchers as revealed in table no.1.

\section{REVIEW ON PHOTOPROTECTION ACTIVITY}

Brown algae showed strong inhibition activity on UV-induced MMP-1 (Matrixmetalloprotein complex) expression lead to photoprotection. ${ }^{54}$ Phycocomponents of Ecklonia stolonifera such as dieckol and eckol inhibit the expression of MMP-1 in the human dermal fibroblast cell line. ${ }^{55}$ Besides, phlorotannin that present in many marine algal species that interfere with the expression of NF-KB and AP-1(activator protein-1) which inhibits the expression of the same complex. ${ }^{56}$ Sometimes, extracellular degradation occurs by MMPs. that require attention towards MMP inhibition. Kim et al. (2011) suggested the role of polysaccharide in reducing the risk of photoprotection by binding with Fibroblast growth factors and protect them from proteolysis. ${ }^{57}$ Some other findings revealed the role of polysaccharide in the minimization of human skin fibers against proteolysis. ${ }^{58}$ Table 2 illustrates the review study on the applicability of marine algae in photoprotection.

\section{CONCLUSION}

This review study provided the various biological activities of different marine macro algaederived phycosubstances. Mainly, this work focusing on two activities: Skin moisturizing and Photoprotection. Seaweeds are richer in carbohydrates, proteins, fatty acids, etc. that worked as a humectant and this can be helpful to hydrates the skin, prevent skin to become rough and flaccid. Another application focused on the protection of the skin against UV-induced damages that is photoprotection. It is possible by inhibiting Matrix Metalloprotein(MMP) activity. Therefore, further investigations should elicit the precise molecular basis of phycocompounds for biological activities as well as understanding the role of marine macroalgal compounds, and their skin benefits would help to contribute to developing novel cosmeceutical preparations. 


\section{Table 1: Skin moisturizing effect exhibited by different marine algae}

\begin{tabular}{|c|c|c|c|}
\hline No. & Name of Algae & Activity & References \\
\hline 1 & $\begin{array}{l}\text { C.tomentosum } \\
\text { A.nodosum }\end{array}$ & Skin moisturization & 59,60 \\
\hline 2 & $\begin{array}{l}\text { Ulva lactuca } \\
\text { Ulva rigida } \\
\text { Ulva rotundata }\end{array}$ & Skin Moisturizing & 61,62 \\
\hline 3 & Durvillea species & Skin Moisturizing & 63,64 \\
\hline 4 & U.pinnatifidia & Skin moisturization & 59,60 \\
\hline 5 & C.crispus & Skin moisturization & 59,60 \\
\hline 6 & Cladosiphonokamuranus & Skin moisturization & 65 \\
\hline 7 & Durvillaea antarctica & Skin moisturization & 66 \\
\hline 8 & $\begin{array}{l}\text { P.palmata } \\
\text { P.umbilicalis }\end{array}$ & Skin Moisturizers & 67,68 \\
\hline 9 & Vertebrata lanosa & Skin moisturizing & 59,60 \\
\hline 10 & $\begin{array}{l}\text { S.japonica } \\
\text { Chondrus crispus } \\
\text { Codium tomentosum }\end{array}$ & Skin moisturization & 69 \\
\hline 11 & Laminaria japonica & Skin moisturizing effect & 70 \\
\hline 12 & Rhizocloniumhieroglyphicum & $\begin{array}{l}\text { Moisturizing effect on } \\
\text { skin }\end{array}$ & 71 \\
\hline 13 & Nostoc commune & Skin Moisturizing & 48 \\
\hline 14 & F.vesiculosus & $\begin{array}{l}\text { Smoothing and skin } \\
\text { conditioning properties }\end{array}$ & 72 \\
\hline 15 & Ulva australis & Moisturizers & 73,74 \\
\hline 16 & Ulva compressa & Smoothing face cream & 75,76 \\
\hline 17 & Genus Nannochloropsis & Skin moisturizing & 77 \\
\hline 18 & $\begin{array}{l}\text { Gracillaria species } \\
\text { Monostroma species }\end{array}$ & Skin Moisturizing & $78,79,80,81$ \\
\hline 19 & Laminaria japonica & $\begin{array}{l}\text { Skin moisturizing } \\
\text { activity }\end{array}$ & 52 \\
\hline 20 & Dunaliella salina & $\begin{array}{l}\text { Improvement of the skin } \\
\text { roughness }\end{array}$ & 43 \\
\hline
\end{tabular}

Table 2: Photoprotection effect revealed by different marine algae.

\begin{tabular}{clll}
\hline No. & Name of Algae & Activity & References \\
\hline 1 & Tetraselmissuecica & Photoprotective activity & 82 \\
\hline 2 & $\begin{array}{l}\text { Catenella repens(Red algae) } \\
\text { Chlamydomonas } \\
\text { hedleyi(Green algae) } \\
\text { Padina crassa(Brown algae) }\end{array}$ & $\begin{array}{l}\text { Photoprotection } \\
\text { (absorb UV radiation) }\end{array}$ & 83,84 \\
\hline 3 & Chlorella sorokiniana & $\begin{array}{l}\text { Photoprotection/Anti } \\
\text { Photoaging }\end{array}$ & 85 \\
\hline 4 & Porphyra species & Photoprotection & 86 \\
\hline 5 & $\begin{array}{l}\text { Ulva lactuca } \\
\text { Ecklonia cava }\end{array}$ & Photoprotection & 87 \\
\hline 6 & Chlorella zofigiensis & Photoprotection & 88 \\
\hline 7 & $\begin{array}{l}\text { Sargassum aquifolium } \\
\text { S.cristaefolium } \\
\text { S.polycystum }\end{array}$ & Antiultraviolet & 89 \\
\hline 8 & $\begin{array}{l}\text { U.lactuca } \\
\text { U.rotundata } \\
\text { U.rigid }\end{array}$ & $\begin{array}{l}\text { A.nodosum } \\
\text { E.cava }\end{array}$ & Protective agent \\
\hline 9
\end{tabular}




\begin{tabular}{|c|c|c|c|}
\hline & C.pilulifera & & \\
\hline 10 & L.okamurae & UV protection & 96 \\
\hline 11 & U.pinnatifida & UV protection & 97 \\
\hline 12 & P.umbilicalis & Sunscreen formulation & 98 \\
\hline 13 & Porphyrayezoensis & UV protection & 99 \\
\hline 14 & $\begin{array}{l}\text { Spirulina sp., Chlorella sp., } \\
\text { Dunaliella sp. }\end{array}$ & Reduce UV induced damage & 100 \\
\hline 15 & $\begin{array}{l}\text { Fucus serratus } \\
\text { Porphyratenera }\end{array}$ & $\begin{array}{l}\text { Protecting agent } \\
\text { Photoprotective activity }\end{array}$ & 101 \\
\hline 16 & Tetraselmisuecica & Sunscreen & 102 \\
\hline 17 & $\begin{array}{l}\text { Sargassum species } \\
\text { Eucheuma cottonii }\end{array}$ & Sunscreen cream & 103 \\
\hline 18 & $\begin{array}{l}\text { Sargassum species } \\
\text { Turbinaria species } \\
\text { Padina species }\end{array}$ & Photoprotective activity & 104 \\
\hline 19 & $\begin{array}{l}\text { Halidryssiliquosa } \\
\text { (Brown macroalga) }\end{array}$ & Sunscreen & 105 \\
\hline 20. & Ulva australis & Natural sunscreen & 67,68 \\
\hline 21 & Sargassum species & $\begin{array}{l}\text { Sunscreen cream } \\
\text { Anti-ultraviolet ray }\end{array}$ & 106,107 \\
\hline 22 & Porphyrayezoensis & UV protection & 108 \\
\hline
\end{tabular}

\section{REFERENCE}

[1] Kalasariya H, Patel V, Patel R, Patel N, Rathwa S, Seaweeds diversity study of selected Beyt Dwarka coast in Gujarat, India. International Journal of Botany Studies, Volume 5; Issue 1; January 2020; Page No. 141-145.

[2] Leonel Pereira, Seaweeds as Source of Bioactive Substances and Skin Care Therapy-Cosmeceuticals, Algotheraphy, and Thalassotherapy Cosmetics 2018, 5, 68; DOI:10.3390/cosmetics5040068

[3] Pereira, L. Algae. Litoral of Viana do Castelo; Câmara Municipal de Viana do Castelo: Viana do Castelo,Portugal, 2010; pp. 7-8. ISBN 978-972-588-217-7.

[4] Pereira, L.; Correia, F. AlgasMarinhas da Costa Portuguesa-Ecologia, Biodiversidade e Utilizações; Nota de RodapéEditores: Paris, France, 2015; p. 341. ISBN 978-989-20-5754-5.

[5] Sharma N, Sharma P, Industrial and Biotechnological Applications of Algae: A Review, Journal Of Advances In Plant Biology, Vol-1 Issue 1 Pg. no.- 1, DOI : 10.14302/issn.2638-4469.japb-17-1534

[6] K.Sahayaraj, S.Rajesh, A.Asha, J.M.Rathi\&Patric Raja, Distribution and diversity assessment of the marine macroalgae at four southern districts of Tamil Nadu, India. Indian Journal of Geo-Marine Sciences, Vol,43(4), April 2014,pp.607-617

[7] K. Sahayaraj, Biological Values and Conservation of Marine Algae: An Overview. ISBN - 978-81-927330-7-4.

[8] G Malathi, S Arunprakash, M Arul Kumar, A BaskaraBoopathy, P Rama, Diversity, and Distribution of Macro-Algae in the Gulf of Mannar. International Journal of Pharma Research and Health Sciences. 2018; 6 (1): 2264-68. DOI:10.21276/ijprhs.2018.01.30

[9] Jagbeer Cheema, Aniket Bhattacharya, Ishan Saini, and Ashok Aggarwal Study of seaweeds diversity of port 'Okha' in winter. New York Science Journal 2014;7(9)

[10] Suparna Roy, Harshad Salvi, Bhargav Brahmbhatt, Nilesh Vaghela, Lopamudra Das, And Bharat Pathak. Diversity and distribution of seaweeds in selected reefs and islands in the Gulf of Kachchh. Seaweed Res. Utiln., 37(1):12 - 19, 2015 
[11] TH Dave, DT Vaghela, and BG Chudasama. Status, distribution, and diversity of some macroalgae along the intertidal coast of Okha, Gulf of Kachchh, Gujarat in India. JEZS 2019; 7(3): 327-331

[12] Mukund C Thakur, C R K Reddy, and Bhavanath Jha. Seasonal variation in biomass and species composition of seaweeds stranded along Port Okha, northwest coast of India. J. Earth Syst. Sci. 117, No. 3, June 2008, pp. 211-218

[13] Filaire E, Berthon JY, Nachat-Kappesa R, et al. Commentary on "Marine algae as attractive source to skin care". J Skin. 2018;2(1):3.

[14] LeventAlparslan, Nazim Sekeroglu, AnakeKijjoa, The Potential of Marine Resources in Cosmetics. Curr. Pers. MAPs, 2018, 2, 53-66

[15] Valentina Jesumani, Hong Du, Muhammad Aslam, Pengbing Pei, and Nan Huang 1Potential Use of Seaweed Bioactive Compounds in Skincare-A Review. Mar. Drugs 2019, 17, 688; DOI:10.3390/md17120688

[16] Noel Vinay Thomas and Se-Kwon Kim, Beneficial Effects of Marine Algal Compounds in Cosmeceuticals. Mar. Drugs 2013, 11, 146-164; DOI:10.3390/md11010146

[17] Priyan, S.F.; Kim, K.N.; Kim, D.; Jeon, Y.J. Algal polysaccharides: Potential bioactive substances for cosmeceutical applications. Crit. Rev. Biotechnol. 2019, 39, 99-113.

[18] Gao, X.H.; Zhang, L.; Wei, H.; Chen, H.D. E_cacy and safety of innovative cosmeceuticals. Clin. Dermatol. 2008, 26, 367-374.

[19] Takizawa, T.; Imai, T.; Onose, J.; Ueda, M.; Tamura, T.; Mitsumori, K.; Izumi, K.; Hirose, M. Enhancement of hepatocarcinogenesis by kojic acid in rat two-stage models after initiation with $\mathrm{N}$-bis (2-hydroxypropyl) nitrosamine or $\mathrm{N}$ diethylnitrosamine. Toxicol. Sci. 2004, 81, 43-49.

[20] SnezanaAgatonovic-Kustrin and David W Morton. Cosmeceuticals Derived from Bioactive Substances Found in Marine Algae. Journal of Oceanography and Marine Research. 2013, 1:2 DOI: 10.4172/2332-2632.1000106

[21] Sudhakar, K.; Mamat, R.; Samykano, M.; Azmi, W.H.; Ishak, W.F.W.; Yusaf, T. An overview of marine macroalgae as bioresource. Renew. Sustain. Energy Rev. 2018, 91, 165-179.

[22] Song, Y. S.; Balcos, M. C.; Yun, H. Y.; Baek, K. J.; Kwon, N. S.; Kim, M. K.; Kim, D. S., ERK activation by fucoidan leads to inhibition of melanogenesis in Mel-Ab Cells. Korean J PhysiolPharmacol2015, 19, (1), 29-34.

[23] Ruperez, P.; Ahrazem, O.; Leal, J. A., Potential antioxidant capacity of sulfated polysaccharides from the edible marine brown seaweed Fucus vesiculosus. J Agric Food Chem 2002, 50, (4), 840-5.

[24] Moon, H. J.; Park, K. S.; Ku, M. J.; Lee, M. S.; Jeong, S. H.; Imbs, T. I.; Zvyagintseva, T. N.; Ermakova, S. P.; Lee, Y. H., Effect of Costariacostata fucoidan on the expression of matrix metalloproteinase-1 promoter, mRNA, and protein. J Nat Prod 2009, 72, (10), 1731-1734.

[25] Yang, J. H., Topical application of fucoidan improves atopic dermatitis symptoms in NC/Nga mice. Phytother Res 2012, 26, (12), 1898-903.

[26] Wang, J.; Jin, W.; Hou, Y.; Niu, X.; Zhang, H.; Zhang, Q., Chemical composition, and moisture-absorption/retention ability of polysaccharides extracted from five algae. Int J Biol Macromol2013, 57,26-9.

[27] Qi, H.; Zhang, Q.; Zhao, T.; Hu, R.; Zhang, K.; Li, Z., In vitro antioxidant activity of acetylated and benzoylated derivatives of polysaccharide extracted from Ulva pertusa (Chlorophyta). Bioorg Med Chem Lett 2006, 16, (9), 2441-5. 
[28] Thevanayagam, H.; Mohamed, S. M.; Chu, W. L., Assessment of UVBphotoprotective and antioxidative activities of carrageenan in keratinocytes. J Appl Phycol2014, 26, (4), 1813-1821.

[29] 29.. Yuan, H. M.; Song, J. M.; Zhang, W. W.; Li, X. G.; Li, N.; Gao, X. L., Antioxidant activity and cytoprotective effect of kappa-carrageenan oligosaccharides and their different derivatives. Bioorg Med Chem Lett 2006, 16, (5),1329-1334.

[30] Rajasulochana P, Preethy V. Glimpses on Cosmetic Applications using Marine Red algae. IJPT Sep-2015 Vol. 7 Issue No.2 | 9235-9242

[31] Ji Hye Kim, Jae-Eun Lee, KyoungHeon Kim and Nam Joo Kang, Beneficial Effects of Marine algae-derived Carbohydrates for Skin Health. Mar. Drugs 2018, 16, 459; DOI:10.3390/md16110459

[32] Maria Całka, Paweł J. Pawlica. Substances of natural origin used in the sun protection of the skin. EJMT 3(24) 2019

[33] Bensouilah J, Buck P, Tisserand R, Avis A., Aromadermatology: Aromatherapy in the Treatment and Care of Common Skin Conditions. Abingdon: Radcliffe Publishing Ltd. 2006.

[34] Wellness Advocate OPC-Proanthocyanidin. 2011. A Total Wellness Newsletter. 1994;4:1-4.

[35] Dweck AC, Herbal medicine for the skin - their chemistry and effects on skin and mucous membranes. Pers Care Mag. 2002;3:19-21.

[36] Mishra A.K, Mishra A. Chattopadadhyay P., Herbal cosmeceuticals from ultraviolet B radiation: a review. Trop. J. Pharm. 2011;10(3):351-360.

[37] Gasser P, Lati E, Peno- Mozzarino L. et. al., Cocoa polyphenols and their influence on parameters involved In ex vivo skin restructuring. International Journal of Cosmetic Science 2008;(30):339-345.

[38] Erlund I, Chemical analysis and pharmacokinetics of the flavonoids quercetin, hesperetin, and naringenin in humans. Academic dissertation. Helsinki: University of Helsinki; 2002. National Public Health Institute. The University of Helsinki. Department of Health and Functional Capacity.

[39] Mayer P, Pittermann W, Wallat S, The effects of vitamin E on the skin. Cosmet Toiletries. 1993;108:99-109.

[40] Choi, J.W., Kwon, S.H., Huh, C.H., Park, K.C. \&Youn, S.W., The influences of skin visco-elasticity, hydration level, and aging on the formation of wrinkles: a comprehensive and objective approach. Skin Research and Technology, (2013) 19: e349-e355.

[41] Flynn, T.C., Petros, J., Clark, R.E. \&Viehman, G.E., Dry skin, and moisturizers. Clinics in Dermatology, (2001) 19: 387-392.

[42] Harding, C.R., Watkinson, A., Rawlings, A.V. and Scott, I.R. Dry skin, moisturization, and corneodesmolysis. International Journal of Cosmetic Science, (2000) 22: 21-52.

[43] Z.Ma'or, G.Meshulam-Simon, S.Yehuda, and J.A.GaVrieli, Antiwrinkle, and skin moisturizing effects of the mineral-algal-botanical complex.Journal Of Cosmetic Science, December 15, 1999.

[44] Bin, B.H.; Kim, S.T.; Bhin, J.; Lee, T.R.; Cho, E.G., The development of sugar-based anti-melanogenic agents. Int. J. Mol. Sci. 2016, 17, 583

[45] Kobayashi, R.; Takisada, M.; Suzuki, T.; Kirimura, K.; Usami, S. Neo, Agarobiose as a novel moisturizer with whitening effect. Biosci. Biotechnol. Biochem. 1997, 61, 162-163.

[46] Peyman Derikvand, Carole A. Llewellyn, and Saul Purton., Cyanobacterial metabolites as a source of sunscreens and moisturizers: a comparison with current 
synthetic

compounds.

European

Journal

of

Phycology.

http://dx.doi.org/10.1080/09670262.2016.1214882

[47] Lisby, S., Gniadecki, R. \& Wulf, H.C., UV-induced DNA damage in human keratinocytes: quantitation and correlation with long-term survival. Experimental Dermatology, (2005) 14: 349-355.

[48] Varsha Vaibhav, Sangeeta Sahasrabuddhe., 'BLUE' is the new 'GREEN' for the Cosmetic Industry. 2018 IJRTI Volume 3, Issue 10

[49] Jean-Baptiste Guillerme, Céline Couteau and Laurence Coiffard, Applications for Marine Resources in Cosmetics. Cosmetics 2017, 4, 35; doi:10.3390/cosmetics4030035

[50] Afroz Jahan, Iffat Zareen Ahmad, Nida Fatima, Vaseem A. Ansari1, and Juber Akhtar, Algal bioactive compounds in the cosmeceutical industry: a review. PhycologiaVolume 56 (4), 410-422.

[51] Surabhi Joshi, Roshani Kumari, Vivek N. Upasani, Applications of Algae in Cosmetics: An Overview. International Journal of Innovative Research in Science, Engineering and Technology Vol. 7, Issue 2, February 2018. DOI:10.15680/IJIRSET.2018.0702038

[52] Jae-Suk Choi, Woi Sook Moon, Ji Na Choi, Kee Hun Do, Sun Hwa Moon, Kwang Keun Cho, Chae-Jeong Han, and In Soon Choi., Effects of seaweed Laminaria japonica extracts on skin moisturizing activity in vivo. J. Cosmet. Sci., 64, 193-205 (May/June 2013)

[53] SnezanaAgatonovic-Kustrin and David W Morton, Cosmeceuticals Derived from Bioactive Substances Found in Marine Algae. Journal of Oceanography and Marine Research. DOI: 10.4172/2332-2632.1000106.

[54] Babitha, S.; Kim, E.K., Effect of Marine Cosmeceuticals on the Pigmentation of Skin. In Marine Cosmeceuticals: Trends and Prospects; Kim, S.K., Ed.; CRC Press: Boca Raton, FL, USA, 2011; pp. 63-66.

[55] Joe, M.J.; Kim, S.N.; Choi, H.Y.; Shin, W.S.; Park, G.M.; Kang, D.W.; Kim, Y.K., The inhibitory effects of eckol and dieckol from Ecklonia stoloniferaon the expression of matrix metalloproteinase-1 in human dermal fibroblasts. Biol. Pharm. Bull. 2006, 29, 1735-1739.

[56] Belford, D.A.; Hendry, I.A.; Parish, C.R., Investigation of the ability of several naturally occurring and synthetic polyanions to bind to and potentiate the biological activity of acidic fibroblast growth factor. J. Cell. Physiol. 1993, 157, 184-189.

[57] Kim, S.K.; Thomas, N.V.; Li, X.F., Phlorotannins, and Fucoidans From Marine Macroalgae as Matrix Metalloproteinase Inhibitory Substances and their possible application as medicinal foods. Advances in Food and Nutrition Research Series 64; Academic Press Inc.: Waltham, MA, USA, 2011; pp. 129-139.

[58] Senni, K.; Gueniche, F.; Foucault-Bertaud, A.; Igondjo-Tchen, S.; Fioretti, F.; Colliec-Jouault, S.; Durand, P.; Guezennec, J.; Godeau, G.; Letourneur, D., Fucoidan a sulfated polysaccharide from brown algae is a potent modulator of connective tissue proteolysis. Arch. Biochem. Biophys. 2006, 445, 56-64.

[59] Wang, H.-M.; Chou, Y.-T.; Wen, Z.-H.; Wang, C.-Z.; Wang, C.-H.; Ho, M.-L., Novel biodegradable porous scaffold applied to skin regeneration. PLoS ONE 2013, 8, e56330

[60] Wang, J.; Jin, W.; Hou, Y.; Niu, X.; Zhang, H.; Zhang, Q. Chemical composition and moisture-absorption/retention ability of polysaccharides extracted from five algae. Int. J. Biol. Macromol. 2013, 57, 26-29.

[61] Lahaye, M.; Robic, A., Structure and functional properties of ulvan, a polysaccharide from green seaweeds. Biomacromolecules 2007, 8, 1765-1774. 
[62] Robic, A.; Rondeau-Mouro, C.; Sassi, J.F.; Lerat, Y.; Lahaye, M., Structure, and interactions of ulvan in the cell wall of the marine green algae Ulva rotundata (Ulvales, Chlorophyceae). Carbohydr. Polym. 2009, 77, 206-216.

[63] Mafinowska, P. Algae extracts as active cosmetic ingredients. Zeszy. Naukowe2011, 212, 123-129.

[64] Tonnesen, H.H.; Karlsen, J., Alginate in drug delivery systems. Drug. Dev. Ind. Pharm. 2002, 2, 621-630.

[65] Wang, H.-M.; Chou, Y.-T.; Wen, Z.-H.; Wang, C.-Z.; Wang, C.-H.; Ho, M.-L. The novel biodegradable porous scaffold is applied to skin regeneration. PLoS ONE 2013, 8, e56330.

[66] Wang, J.; Jin, W.; Hou, Y.; Niu, X.; Zhang, H.; Zhang, Q., Chemical composition, and moisture-absorption/retention ability of polysaccharides extracted from five algae. Int. J. Biol. Macromol. 2013, 57, 26-29.

[67] Borowitzka, M.A., High-value products from microalgae - their development and commercialization. J. Appl. Phycol. 2013, 25, 743-756.

[68] Houston, M.C., Nutraceuticals, vitamins, antioxidants, and minerals in the prevention and treatment of hypertension. Prog. Cardiovasc. Dis. 2005, 47, 396-449.

[69] Wang, J., Jin, W., Hou, Y., Niu, X., Zhang, H. and Zhang, Q; Chemical composition and moisture-absorption/retention ability of polysaccharides extracted from five algae. International Journal of Biological Macromolecules, vol. 57, 26-29, (2013)

[70] Choi, J.-S.; Moon, W.S.; Choi, J.N.; Do, K.H.; Moon, S.H.; Cho, K.K.; Han, C.-J.; Choi, I.S.; Effects of seaweed Laminaria japonica extracts on skin moisturizing activity in vivo. J. Cosmet. Sci., 64, 193-209, (2013)

[71] Leelapornpisid, P.; Mungmai, L.; Sirithunyalug, B.; Jiranusornkul, S.; Peerapornpisal, Y.; A novel moisturizer extracted from freshwater macroalga [Rhizocloniumhieroglyphicum(C.Agardh) Kützing] for skincare cosmetic. Chiang Mai J. Sci., 41, 1195- 1207, (2014)

[72] Fujimura T, Tsukahara K, Moriwaki S, Kitahara T, Takema Y (2000) Effects of natural product extracts on contraction and mechanical properties of fibroblast populated collagen gel. Biol Pharm Bull 23: 291-297.

[73] Borowitzka, M.A. High-value products from microalgae-Their development and commercialization. J. Appl. Phycol. 2013, 25, 743-756.

[74] Houston, M.C. Nutraceuticals, vitamins, antioxidants, and minerals in the prevention and treatment of hypertension. Prog. Cardiovasc. Dis. 2005, 47, 396-449.

[75] Bellou, S.; Aggelis, G; Biochemical activities in Chlorella sp. and Nannochloropsis salina during lipid and sugar synthesis in a lab-scale open pond simulating reactor. J. Biotechnol.; Vol-164; pp-318-329, .(2012)

[76] Wang, J., Jin, W., Hou, Y., Niu, X., Zhang, H., and Zhang, Q. "Chemical composition and moisture-absorption/retention ability of polysaccharides extracted from five algae". International Journal of Biological Macromolecules, vol. 57, pp. 26-29, 2013.

[77] Daniel, S., Cornelia, S., Fred, Z., and Mibelle, A. G., UV-A sunscreen from red algae for protection against premature skin aging, Cosmetics and toiletries manufacture worldwide.139-143

[78] Yun, E.J.; Yu, S.; Kim, K.H., Current knowledge on agarolytic enzymes and the industrial potential of agar-derived sugars. Appl. Microbiol. Biotechnol. 2017, 101, 5581-5589.

[79] Seedevi, P.; Moovendhan, M.; Viramani, S.; Shanmugam, A., Bioactive potential and structural characterization of sulfated polysaccharide from seaweed (Gracilariacorticata). Carbohydr. Polym. 2017, 155, 516-524. 
[80] Souza, B.W.S.; Cerqueira, M.A.; Bourbon, A.I.; Pinheiro, A.C.; Martins, J.T.; Teixeira, J.A.; Coimbra, M.A.; Vicente, A.A., Chemical characterization and antioxidant activity of sulfated polysaccharide from the red seaweed Gracilariabirdiae. Food Hydrocoll. 2012, 27, 287-292.

[81] Cheong, K.L.; Qiu, H.M.; Du, H.; Liu, Y.; Khan, B.M., Oligosaccharides derived from red seaweed: Production, properties, and potential health and cosmetic applications. Molecules 2018, 23, 2451.

[82] Sansone, C., Galasso, C., Orefice, I., Nuzzo, G., Luongo, E., Cutignano, A., Romano, G., Brunet, C., Fontana, A., Esposito, F. and Ianora, A. The green microalga Tetraselmissuecicareduces oxidative stress and induces repairing mechanisms in human cells. Scientific Reports, vol. 7, 2017.

[83] Suh SS, Hwang J, Park M, Seo HH, Kim HS, Lee JH, et al., Anti-inflammation activities of mycosporine-like amino acids (MAAs) in response to UV radiation suggest a potential anti-skin aging activity. Mar Drugs 2014;12:5174-5187.

[84] Gao Q, Garcia-Pichel F. Microbial ultraviolet sunscreens. Nat Rev Microbiol 2011;9:791-802.

[85] Chidambara Murthy KN, Vanitha A, Rajesha J, Mahadeva Swamy M, Sowmya PR, Ravishankar GA. In vivo antioxidant activity of carotenoids from Dunaliella salina a green microalga. Life Sci 2005;76:1381-1390.

[86] Schubert N, Garcia-Mendoza E, Pacheco-Ruiz I. Carotenoid composition of marine red algae. J Phycol2006;42:1208-1216.

[87] Talero E, Garc_1a-Mauri no S, _Avila-Rom_an J, Rodriguez-Luna A, Alcaide A, Motilva V. Bioactive compounds isolated from microalgae in chronic inflammation and cancer. Mar Drugs 2015;13: 6152-6209.

[88] Wang T, J_onsd_ottir R, Liu H, Gu L, Kristinsson HG, Raghavan S, et al. Antioxidant capacities of phlorotannins extracted from the brown algae Fucus vesiculosus. J Agric Food Chem 2012;60:5874-5883.

[89] K. L. Lann et al., Total phenolic, size-fractionated phenolics and fucoxanthin content of tropical Sargassaceae (Fucales, Phaeophyceae) from the South Pacific Ocean: spatial and specific variability, Phycological Research, vol.60, no.1, pp.37-50, 2012.

[90] Lahaye, M.; Robic, A. Structure and functional properties of ulvan, a polysaccharide from green seaweeds. Biomacromolecules 2007, 8, 1765-1774.

[91] Robic, A.; Rondeau-Mouro, C.; Sassi, J.F.; Lerat, Y.; Lahaye, M. Structure and interactions of ulvan in the cell wall of the marine green algae Ulva rotundata (Ulvales, Chlorophyceae). Carbohydr. Polym. 2009, 77, 206-216.

[92] Thomas, N.V.; Kim, S.K., Beneficial effects of marine algal compounds in cosmeceuticals. Mar. Drugs 2013, 11, 146-164.

[93] Stengel, D.B.; Connan, S.; Popper, Z.A., Algal chemodiversity, and bioactivity: sources of natural variability and implications for commercial application. Biotechnol. Adv. 2011, 29, 483-501.

[94] Borowitzka, M.A., High-value products from microalgae-their development and commercialization. J. Appl. Phycol. 2013, 25, 743-756.

[95] Ryu, B.; Li, Y.; Qian, Z.J.; Kim, M.M.; Kim, S.K., Exhibitory effects of compounds from brown alga Ecklonia cava on the human osteoblasts. J. Biotech. 2008, 136, 577588.

[96] Heo, S.-J.; Ko, S.-C.; Kang, S.-M.; Cha, S.-H.; Lee, S.-H.; Kang, D.-H.; Jung, W.-K.; Affan, A.; Oh, C.; Jeon, Y.-J. Inhibitory effect of diphlorethohydroxycarmalol on melanogenesis and its protective effect against UV-B radiation-induced cell damage. Food Chem. Toxicol. 2010, 48, 1355-1361. 
[97] Fitton, J.H.; Dell'Acqua, G.; Gardiner, V.-A.; Karpiniec, S.S.; Stringer, D.N.; Davis, E. Topical benefits of two fucoidan-rich extracts from marine macroalgae. Cosmetics 2015, 2, 66-81.

[98] Mercurio, D.G.; Wagemaker, T.A.L.; Alves, V.M.; Benevenuto, C.G.; Gaspar, L.R.; Maia Campos, P.M., In vivo photoprotective effects of cosmetic formulations containing UV filters, vitamins, Ginkgo biloba, and red algae extracts. J. Photochem. Photobiol. B Biol. 2015, 153, 121-126.

[99] Kim, S.; You, D.H.; Han, T.; Choi, E.M. Modulation of viability, and apoptosis of UVB-exposed human keratinocyte HaCaT cells by aqueous methanol extract of laver (Porphyrayezoensis). J. Photochem. Photobiol. B 2014, 141, 301-307.

[100] Renimel, J. Berthon, J. Cadoret, M. Bey; Marine algae as an attractive source to skincare. Free Radical research Journal 51, 555-567, (2017)

[101] Isaka, S.; Cho, K.; Nakazono, S.; Abu, R.; Ueno, M.; Kim, D.; Oda, T., Antioxidant and anti-inflammatory activities of porphyran isolated from discolored nori (Porphyrayezoensis). Int. J. Biol. Macromol. 2015, 74,68-75.

[102] Kim, J.H.; Yun, E.J.; Yu, S.; Kim, K.H.; Kang, N.J., Different Levels of Skin Whitening Activity among 3,6-Anhydro-l-galactose, Agarooligosaccharides, and Neoagarooligosaccharides. Mar. Drugs 2017, 15, 321.

[103] Nurjanah, N Luthfiyana, T Hidayat, M Nurilmala, and E Anwar Utilization of seaweed porridge Sargassum sp. and Eucheuma cottoniias cosmetic in protecting the skin. Earth Environ. Sci. 278 012055. DOI:10.1088/1755-1315/278/1/012055

[104] Chatrien A. Sinjal, Rizald M. Rompas, Deiske A. Sumilat, Edi Suryanto, Antioxidant, and Photoprotective activity of Brown Seaweed from North Sulawesi Coast. International Journal of ChemTech Research. Vol.11 No.06, pp 121-133, 2018.

[105] Le LannKlervi, SurgetGwladys, Couteau Celine, Coiffard Laurence, Cerantola Stephane, Gaillard Fanny, Larnicol Maud, ZubiaMayalen, Guerard Fabienne, Poupart Nathalie, Stiger-Pouvreau Valerie, Sunscreen, antioxidant, and bactericide capacities of phlorotannins from the brown macroalga Halidryssiliquosa. Journal of Applied Phycology December 2016, Volume 28 Issue 6 Pages 3547-3559

[106] Nurjanah, Mala Nurilmala, Effionora Anwar, Novi Luthfiyana, and TaufikHidayat, Identification of Bioactive Compounds of Seaweed Sargassum sp. and Eucheuma cottoniiDoty as a Raw Sunscreen Cream Proceedings of the Pakistan Academy of Sciences: Life and Environmental Sciences 54 (4): 311-318 (2017)

[107] Devi Suryani Permata Sari, Eka Saputra, Mochammad Amin Alamsjah, Potential of Fucoxanthin Content in Sargassum sp. on Sunscreen Cream Preparation. International Journal of Recent Technology and Engineering (IJRTE) ISSN: 2277-3878, Volume-7 Issue-6S2, April 2019

[108] Mercurio, D.G.; Wagemaker, T.A.L.; Alves, V.M.; Benevenuto, C.G.; Gaspar, L.R.; Campos, P.M. In vivo photoprotective effects of cosmetic formulations containing UV filters, vitamins, Ginkgo biloba, and red algae extracts. J. Photochem. Photobiol. B 2015, 153, 121-126.

\section{ACKNOWLEDGMENTS:}

I am very much grateful to the other co-authors for contributing and sharing their knowledge. As well as I am thankful to the Department of Microbiology, Smt. S. S. Patel Nootan Science \& Commerce College, Sankalchand Patel University, Visnagar for providing facilities to complete this work. 